\title{
The chromium concentration in organs and tissues of rats fed a diet enriched in chromium
}

\author{
E. Arkuszewska \\ Warsaw Agricultural University, \\ Department of Animal Nutrition and Feed Science \\ Ciszewskiego 8, 02-786 Warsaw, Poland
}

\begin{abstract}
The concentration of chromium was determined in the tissues of growing rats after the addition to the diet of a yeast preparation with an increased chromium content (III). The experiment was carried out on 16 male Wistar rats divided in two groups and fed mixtures that were supplemented with chromium in the following quantities in the particular groups (in $\mathrm{mg} \cdot \mathrm{kg}^{-1}$ ): I-0.19; II-0.57. Supplementation of chromium did not affect its content in blood and M. longissimus dorsi but substantially increased it in the kidneys, liver, skin with hair, and pancreas.
\end{abstract}

KEYS WORDS: yeast, chromium, rat, organs, tissues

\section{INTRODUCTION}

Chromium (III) is a trace element essential for humans (Jeejebhoy et al., 1977) and animals (Schwartz and Mertz, 1959), since as a component of glucose tolerance factor (GTF) it supports insulin action, participates in the regulation of hormone secretion, and in the metabolism of proteins, sugars and fats (Ducros, 1992; Anderson et al., 1996). Chromium deficit appears as a result of various stress situations such as transport, high animal density, or rapid growth rate, and also in young animals fed high energy diets resulting in full mobilization of insulin and depletion of chromium stores in the body (Moonsie-Shageer and Mowat, 1993).

In recent years, many investigations were performed on the effects of chromium (III) supplementation not only on animal health, performance and blood biochemical indices but also on the quality of animal products. Yeast

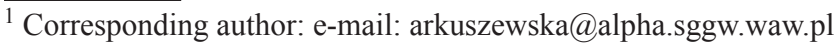


preparations were used as the source of organic chromium, which has a higher biological activity than its inorganic forms (Anderson et al., 1996).

The aim of the present work was to determine the chromium concentration in organs and tissues of rats fed a diet supplemented with a yeast preparation containing an increased level of trivalent chromium.

\section{MATERIAL AND METHODS}

The experiment was performed during 4 weeks on 16 male Wistar rats of initial mean body weigt $62 \mathrm{~g}$, divided in two groups. The animals were maintained in individual cages with free access to feed and water, in a room at $21^{\circ} \mathrm{C}, 50-70 \%$ humidity and $12 \mathrm{~h} / 12 \mathrm{~h}$ light regimen. The animals were fed ad libitum a semi-synthetic (casein) diet according to NRC (1995) supplemented or not supplemented with yeast preparation Co-Factor III (Alltech, Nicholasville, Biotechnology Center, USA) of $0.5 \mathrm{gkg}^{-1}$.

Feed intake and body weight were registered. At the end of the experiment the rats were anaesthetized, blood was collected and the longest muscle of the back (M. longissimus dorsi), the skin, liver, kidney, and pancreas were sampled. The chromium concentration in the diet and rat tissues was determined by atomic absorption spectrophotometry AAS (AOAC, 1980) after dry mineralization. The results were subjected to one-factorial variance analysis ANOVA, using the program Statgraphics 6.0 Plus.

\section{RESULTS AND DISCUSSION}

The chromium concentration in the unsupplemented control (C) diet was 0.19 $\mathrm{mg} \mathrm{Crkg}{ }^{-1}$, and in the yeast preparation, $757 \mathrm{mg} \mathrm{Crkg}^{-1}$. Supplementation of diet C with $0.5 \mathrm{~g}$ yeast increased the $\mathrm{Cr}$ content by $0.380 \mathrm{mg} \mathrm{kg}^{-1}$ up to $0.570 \mathrm{mg} \mathrm{Crkg}^{-1}$ in the experimental diet. Final body weight and feed/gain were significantly higer in rats fed the Cr-supplemented than the control diet ( $241 \mathrm{~g}$ and $2.5 \mathrm{~g}$ vs $222 \mathrm{~g}$ and $1.9 \mathrm{~g}$, respectively).

Feeding the diet supplemented with the yeast preparation increased the chromium concentration in tissues and organs (Table 1).

The increase in blood serum and M. longissimus dorsi was rather small and nonsignificant, while in the kidney, liver, skin with hair, and pancreas it was greater and statistically significant. The results point to the accumulation of chromium in these organs when a diet containing $0.570 \mathrm{mg} \mathrm{Cr}(\mathrm{III}) \mathrm{kg}^{-1}$ mixture is fed, and confirm the tendency towards deposition of heavy metals, including chromium, in the parenchymatous organs. 
Table 1. Chromium concentration in rat $(n=5)$ tissues, $n g . \mathrm{g}^{-1}$ fresh tissue

\begin{tabular}{lccccc}
\hline \multirow{2}{*}{ Tissue } & \multicolumn{2}{c}{ Group } & & \multicolumn{2}{c}{ ANOVA } \\
\cline { 2 - 3 } \cline { 5 - 6 } \cline { 5 - 6 } Blood serum & control $(\mathrm{Cr}-)$ & experimental $(\mathrm{Cr}+)$ & & SEM & $\mathrm{P}$ \\
M. longissimus dorsi & 1.48 & 1.59 & & 0.375 & $\mathrm{NS}$ \\
Kidney & 6.28 & 8.55 & & 0.621 & $\mathrm{NS}$ \\
Liver & $13.91^{\mathrm{a}}$ & $18.46^{\mathrm{b}}$ & & 1.076 & 0.0211 \\
Skin with hair & $2.35^{\mathrm{a}}$ & $4.27^{\mathrm{b}}$ & & 0.520 & 0.0343 \\
Pancreas & $40.53^{\mathrm{A}}$ & $60.41^{\mathrm{B}}$ & & 3.780 & 0.0043 \\
SEM- mean standard error ${ }^{\mathrm{A}, \mathrm{B}}-\mathrm{P}<0.01^{\text {a.b }}-\mathrm{P}<0.05$ & $59.87^{\mathrm{B}}$ & & 1.820 & 0.0012 \\
\hline
\end{tabular}

These results agree with those of Wallach (1985), Anderson et al. (1997), Hepburn and Vincent (2002). Feeding diets supplemented with chromium (III) in the form of chromium dinicotinic acid diglycine cysteine glutamic acid (GTF) in the amount of $5 \mathrm{mgkg}^{-1}$ diet increased the chromium concentration in rat liver dry matter from $23{\mathrm{ng} \cdot \mathrm{g}^{-1}}$ liver in the control group to $805 \mathrm{ng}^{-1}$ in experimental animals (Anderson et al., 1996).

The accumulation of chromium in skin and hair is in agreement with accumulation of heavy metals and other toxic substances in dead tissues such as feathers, hair, and horns, which is a way of eliminating toxins from the organism. Also Wallach (1985) found a higher content of chromium in hair and skin than in other tissues.

Among the analysed organs, the pancreas had the highest chromium concentration and responded in the most marked way to the chromium supplement. This is probably related to the metabolic function of chromium and its presence in the structure of GTF, which is synthesized and secreted by the pancreas. This may indicate that the pancreas is the target organ for chromium fed at physiological doses.

\section{CONCLUSIONS}

The addition of trivalent chromium in the form of yeast at a dose of $380 \mathrm{ppb}$ did not significantly affect the deposition of this element in the M. longissimus dorsi, while it increased chromium accumulation in the liver, kidneys, skin with hair, and pancreas.

\section{REFERENCES}

Anderson R.A., Bryden N.A., Polansky M.M., 1997. Lack of toxicity of chromium chloride and chromium picolinate in rats. J. Amer. Coll. Nutr. 16, 273-279

Anderson R.A., Bryden N.A., Polansky M.M., Gautsch K., 1996. Dietary chromium effects on tissue chromium concentrations and chromium absorption in rats. J. Trace Elem. Exp. Med. 9, 11-25

Ducros V., 1992. Chromium metabolism. Biol. Tr. Elem. Res. 32, 65-77 
Hepburn D.D., Vincent J.B., 2002. In vivo distribution of chromium from chromium picolinate in rats and implications for the safety of the dietary supplement. Chem. Res. Toxicol. 15, 93-100

Jeejebhoy K.N., Chu R.C.., Marliss E.B., Greenberg G.R., Bruce-Robertson A., 1977. Chromium deficiency, glucose intolerance and neuropathy reversed by chromium supplementation in a patient receiving long-term total parenteral nutrition. Amer. J. Clin. Nut. 30, 531-538

Moonsie-Shageer S., Mowat D.N., 1993. Effect of level of supplemental chromium on performance, serum constituents, and immune status of stressed feeder calves. J. Anim. Sci. 71, 232-238

Mowat D.N., 1993. Organic chromium: a new nutrient for stressed animals. Alltech's $9^{\text {th }}$ Annual Symposium on Biotechnology in the Feed Industry, pp. 275-282

Schwartz K., Mertz W., 1959. Chromium (III) and the glucose tolerance factor. Arch. Biochem. Biophys. 85, 292-295

Wallach S., 1985. Clinical and biochemical aspects of chromium deficiency. J. Amer. Coll. Nutr. 4, $107-120$

\section{STRESZCZENIE}

\section{Koncentracja chromu w tkankach szczurów po zastosowaniu dodatku do diet drożdży o podwyższonej zawartości chromu}

Określono koncentrację chromu w tkankach rosnących szczurów po zastosowaniu dodatku do diety preparatu drożdżowego o podwyższonej zawartości chromu (III). Doświadczenie przeprowadzono na 16 samcach szczurach rasy Wistar, podzielonych na 2 grupy i żywionych mieszankami, które różniły się zawartością chromu (w mg: $\left.\mathrm{kg}^{-1}\right)$ : I-0,19; II-0,570. Dodatek chromu nie wpłynął na jego koncentrację w krwi i M. longissimus dorsi, a zwiększył istotnie jego zawartość w wątrobie, nerkach, skórze i włosach oraz w trzustce. 